\title{
Compressive and Flexural Strengths for Considerable Volume Fly-Ash Concrete
}

\author{
Athanase Ndihokubwayo \\ Higher Teacher Training School (Ecole Normale Supérieure), Applied Sciences Department, Civil Engineering Section \\ Boulevard du 28 Novembre, Bujumbura, Burundi
}

\begin{abstract}
The use of considerable volume of fly ash concrete in replacement of cement is economically and environmentally benefic because the fly ash is cheaper and produces fewer emissions of greenhouse gases than the conventional Portland cement. By using 30; 40 and 50 percent of fly ash in cementitious materials, after comparing different results of samples tested, the 28 days high-performance fly ash concrete resisted to the compressive loading forces respectively equal to $30.9 \mathrm{MPa}$; 29.7MPa and 26.2 $\mathrm{MPa}$ while for flexural loading forces, the high-performance fly ash concrete resisted respectively 5.1 MPa; 4.0MPa and 3. $9 \mathrm{MPa}$. These results were found after an experimental study done in the concrete laboratory and may inspire the sustainable construction especially for infrastructures with no high loading forces.
\end{abstract}

Keywords Considerable Volume of Fly Ash Concrete, Compressive Strength, Flexural Strength

\section{Introduction}

The high-volume fly ash concrete (HVFAC) system has emerged as a future powerful concrete system that would be far more durable and resource-efficient than those made of conventional Portland cement concrete. As the Portland cement industry is responsible for approximately 7 percent of the world's carbon dioxide emission, Malhotra et al.[1] proposed that the fly ash content must be above 50 percent by mass of total cementitious for making a concrete for sustainable development They also proposed that for concrete mixture with specified 28 days compressive strength of $30 \mathrm{MPa}$ or higher, slumps $>150 \mathrm{~mm}$, and water-to- cementitious materials ratio of the order of 0.30 , the use of highrange superplasticizers is mandatory. For concrete mixture with slumps less than $150 \mathrm{~mm}$ and 28 days compressive strength of less than $30 \mathrm{MPa}$, high fly ash concrete mixture with a water-to-cementitious material ratio of the order of 0.4 may be used without superplasticizers. The Confederation of Indian Industry; centre of excellence for sustainable development[2] proposed that for obtaining a superior performance of HVFAC, the water-to-cementitious ratio should be bellow 0.4 and preferably $\leq 0.35$. The use of superplasticizer is most of the time essential.

Vargas and José A.[3] defined a HVFAC as a concrete in which at least 50 percent by weight or mass of the cementitious material content is the fly ash. The applications (such as foundations) where strengths of 21 to $28 \mathrm{MPa}$ are acceptable

* Corresponding author:

athanand@yahoo.com (Athanase Ndihokubwayo)

Published online at http://journal.sapub.org/jce

Copyright (C) 2011 Scientific \& Academic Publishing. All Rights Reserved and high early strength is not required may be produced without special admixtures. Compared to the conventional Portland concrete, the HVFAC has some qualities: lower cost, very high environmental benefits (reduced $\mathrm{CO}_{2}$ ), easier flowability and workability, negligible bleeding, quicker finishing, higher ultimate strength up to 90 days, higher crack resistance, very higher resistance to penetration of chloride ions after 3 months and very higher electrical resistivity after 3 months.

About the volume the emissions of greenhouse gases which can be reduced, Ehrenberg and Geisler[4] wrote that the replacement of 1 ton of Portland cement by the fly ash reduces the overall $\mathrm{CO}_{2}$ emissions by approximately 1 ton. Langley et al.[5] specified that another benefit of using fly ash in concrete is that fly ash makes beautiful architectural concrete because its light in color and its extreme workability ensures smoother finishes. In addition, fly ash in plaster virtually eliminates defects like crazing, map cracking, drying shrinkage cracks, grinning, expansion and popping.

With the aim to contribute to the study of the compressive and flexural loading resistance for a considerable volume fly ash concrete, a total of 144 samples were made in the concrete laboratory (72 for compressive test and 72 for flexural test).

\section{Materials}

The materials used were composed by the cementitious, aggregates, superplasticizer and pure water. The chemical properties of the cementitious used are shown in the Table $2-1$.

The specific surface of the cement used is $310 \mathrm{~m}^{2} / \mathrm{kg}$ while 
the fly ash fineness $(80 \mu \mathrm{m}$ residue on sieve) is 24 percent. The mechanical properties of aggregates used are shown below in Table 2-2.

Some chemical properties for the superplasticizer used: Na2SO4:10.2\%; Solid Content: 50\%; Chlorine ion: 0.01\%; PH: 6.5-8.5; Fluidity: E250 mm; Density: $1.08 \mathrm{~g} / \mathrm{cm}^{3}$

Table 1. Cementitious chemical properties

\begin{tabular}{|c|c|c|}
\hline \multirow{2}{*}{ Spec. } & \multicolumn{2}{|c|}{ Cementitious (\%) } \\
\cline { 2 - 3 } & Cement (42.5) & Fly ash (F) \\
\hline $\mathrm{SiO}_{2}$ & 21.47 & 50.0 \\
\hline $\mathrm{Al}_{2} \mathrm{O}_{3}$ & 5.81 & 32.85 \\
\hline $\mathrm{FeO}_{3}$ & 4.04 & 4.21 \\
\hline $\mathrm{CaO}$ & 59.64 & 4.91 \\
\hline $\mathrm{MgO}$ & 3.24 & 1.58 \\
\hline $\mathrm{Na}_{2} \mathrm{O}$ & - & 1.42 \\
\hline $\mathrm{K}_{2} \mathrm{O}$ & - & 1.35 \\
\hline $\mathrm{LOI}$ & 2.44 & 3.22 \\
\hline
\end{tabular}

Table 2. Aggregate properties

\begin{tabular}{|c|c|c|}
\hline Item & Gravel & Sand \\
\hline D max (mm) & 9.52 & 4.75 \\
\hline Specific gravity & 2.64 & 2.65 \\
\hline Absorption (\%) & 1.3 & 1.85 \\
\hline Unit weight (kg/m3) & 1522 & 1761 \\
\hline Passing \#50 sieve (\%) & 0.0 & 8.6 \\
\hline Fineness modulus & 6.32 & 3.24 \\
\hline Compressive strength(MPa) & 93.55 & - \\
\hline Modulus of elasticity(Gpa) & 51.04 & - \\
\hline
\end{tabular}

\section{Materials Proportioning}

The methods used for making the fly ash concrete were based on materials proportioning system according to the percent of the cementitious contents. The Table 3-1 and the Table 3-2 show respectively our proposition for materials proportioning and the volume of materials.

Table 3. Materials proportion

\begin{tabular}{|c|c|c|c|}
\hline \multirow{2}{*}{ FA and C (\%) } & Ref. & W/C & G/S \\
\hline \multirow{3}{*}{30} & 1 & 0.51 & 1.94 \\
\cline { 2 - 4 } 70 & 2 & 0.46 & 2.12 \\
\cline { 2 - 4 } & 3 & 0.46 & 2.12 \\
\cline { 2 - 4 } & 4 & 0.39 & 2.12 \\
\hline \multirow{3}{*}{40} & 5 & 0.51 & 1.94 \\
\cline { 2 - 4 } 60 & 6 & 0.46 & 2.12 \\
\cline { 2 - 4 } & 7 & 0.46 & 2.12 \\
\hline \multirow{3}{*}{50} & 8 & 0.39 & 2.12 \\
\cline { 2 - 4 } & 9 & 0.46 & 2.12 \\
\cline { 2 - 4 } 50 & 10 & 0.51 & 2.12 \\
\cline { 2 - 4 } & 11 & 0.46 & 2.12 \\
\hline \multirow{3}{*}{50} & 12 & 0.39 & 2.12 \\
\hline
\end{tabular}

For compressive samples the moulds size is $150 \mathrm{~mm}$ cubic while for flexural samples the size is $100 \mathrm{~mm} \times 100 \mathrm{~mm}$ x $400 \mathrm{~mm}$.

The concrete -mixer used could mix at once concrete whose volume is the total volume of 6

samples for compressive test and 6 samples for flexural test .

The slump test was done for each fresh concrete and the measure was ranged between 120 and $180 \mathrm{~mm}$. For making the concrete more compact and homogeneous, a vibrating table was used.

Table 4. Volume of materials

\begin{tabular}{|c|c|c|c|c|c|c|c|}
\hline \multirow{2}{*}{$\begin{array}{c}\text { FAC } \\
(\%)\end{array}$} & \multirow{2}{*}{ Ref. } & \multicolumn{7}{|c|}{$\begin{array}{c}\mathrm{C} \\
(\mathrm{kg})\end{array}$} & $\begin{array}{c}\text { FA } \\
(\mathrm{kg})\end{array}$ & $\begin{array}{c}\mathrm{W} \\
(\mathrm{L})\end{array}$ & $\begin{array}{c}\mathrm{G} \\
(\mathrm{kg})\end{array}$ & $\begin{array}{c}\mathrm{S} \\
(\mathrm{kg})\end{array}$ & $\begin{array}{c}\mathrm{Sp} \\
(\mathrm{kg})\end{array}$ \\
\hline \multirow{3}{*}{$\begin{array}{c}30 \\
70\end{array}$} & 1 & 17.8 & 7.6 & 9.1 & 51.2 & 26.4 & - \\
\cline { 2 - 9 } & 2 & 15.5 & 6.6 & 7.13 & 51.3 & 24.17 & - \\
\cline { 2 - 9 } & 3 & 13.18 & 5.6 & 6.0 & 51.3 & 24.17 & 0.13 \\
\hline & 4 & 15.5 & 6.6 & 6.0 & 51.3 & 24.17 & 0.15 \\
\hline \multirow{4}{*}{40} & 5 & 17.8 & 11.9 & 9.1 & 51.2 & 26.4 & - \\
\cline { 2 - 9 } 60 & 6 & 15.5 & 10.3 & 7.13 & 51.3 & 24.17 & - \\
\cline { 2 - 8 } & 7 & 13.18 & 8.7 & 6.0 & 51.3 & 24.17 & 0.13 \\
\cline { 2 - 8 } & 8 & 15.5 & 10.3 & 6.0 & 51.3 & 24.17 & 0.15 \\
\hline \multirow{4}{*}{50} & 9 & 17.8 & 17.8 & 8.2 & 54.4 & 25.6 & - \\
\cline { 2 - 8 } 50 & 10 & 15.5 & 15.5 & 7.9 & 51.3 & 24.17 & - \\
\cline { 2 - 8 } & 11 & 15.16 & 15.16 & 6.97 & 54.4 & 25.6 & 0.15 \\
\cline { 2 - 8 } & 12 & 17.8 & 17.8 & 6.97 & 54.4 & 25.6 & 0.17 \\
\hline
\end{tabular}

Notice: $\mathrm{C}=$ Cement; $\mathrm{FA}=$ Fly Ash; $\mathrm{W}=$ Water; $\mathrm{G}=$ Gravel; $\mathrm{S}=\mathrm{Sand} ; \mathrm{Sp}=$ Superplasticizer ( $1 \%$ cement weight)

\section{Testing Procedures}

\section{a) Compressive test}

Compressive strength is the capacity of a material to withstand axially directed pushing forces. When the limit of compressive strength is reached, materials are crushed. The cubic concrete specimen is placed on the platform of compression testing machine without any packing between the cube and the steel platens of the testing machine. The load is then applied on a smooth surface on the cube steadily and uniform starting from zero at a rate of $35 \mathrm{~N} / \mathrm{mm}^{2} / \mathrm{min}$ till the cube fails.

\section{b) Flexural Test}

The flexural test is one measure of the tensile strength of concrete. It is a measure of an unreinforced concrete to resist failure in bending. The specimen is placed symmetrically on the load-applying and support blocks. In the present test, the distance between the support-block axis and the extremity of the specimen is $50 \mathrm{~mm}$. The load is then rapidly applied until approximately 50 percent of the breaking load has been reached.

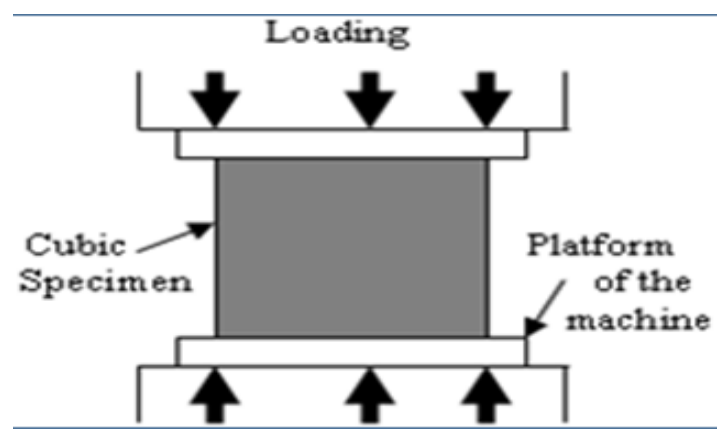

Figure1. Compressive Test 


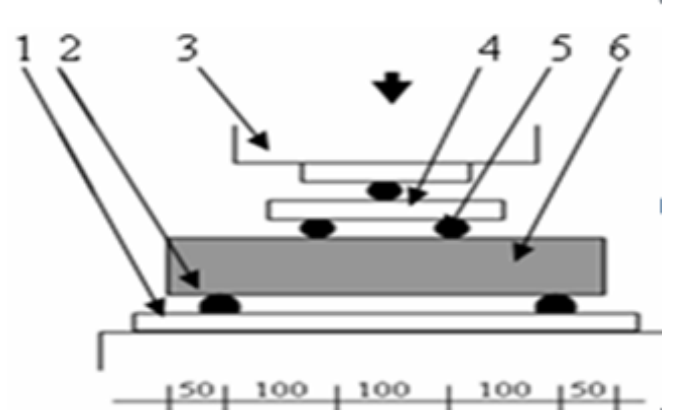

Figure 2. Flexural Test. For Figure.4-2: (1): Bed of testing machine; (2): Load -applying support blocks; (3): Head of testing machine; (4): Loading plate; (5): Steel ball; (6):Rectangular specimen

\section{Test Results and Discussion}

For 28 days fly ash concrete, with water-to-cementitious ratio equal to 0.39 and gravel-to-sand ratio equal to 2.12 , by using superplasticizer product, the experimental results showed that the high- performance compressive strengths of the fly ash concrete were $30.9 \mathrm{MPa} ; 29.7 \mathrm{MPa}$ and $26.2 \mathrm{MPa}$ respectively for 30,40 and 50 percent of fly ash in cementitious materials.

For flexural test results, the high-performance of 28 days fly ash concrete were $5.1 \mathrm{MPa}, 4 \mathrm{MPa}$ and $3.9 \mathrm{MPa}$ respectively for 30; 40 and 50 percent of fly ash in cementitious materials. The

water-to-cementitious ratio and the gravel-to-sand ratio were 0.46 and 2.12 for 30 percent while they were 0.39 and 2.12 for 40 and 50 percent of fly ash in cementitious materials.

The superplasticizer used played a big part in concrete strengthening comparatively to the concrete samples made without the product.

By analyzing the charts (Figure 5-1 and Figure 5-2), the allures of charts 7 days and 28 days are not exactly proportional; either for compressive or flexural test results; this because the climatic and storage conditions varied and changed the parameters of concrete hardening.

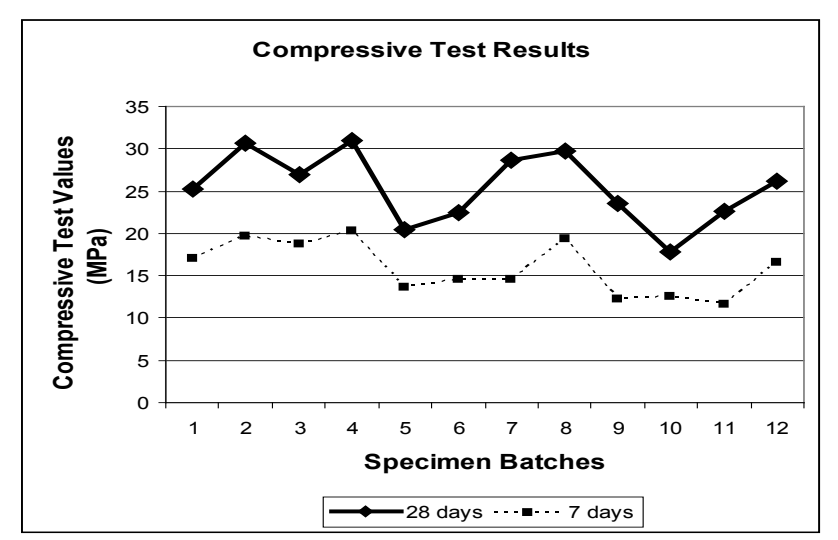

Figure 3. Compressive Result Charts

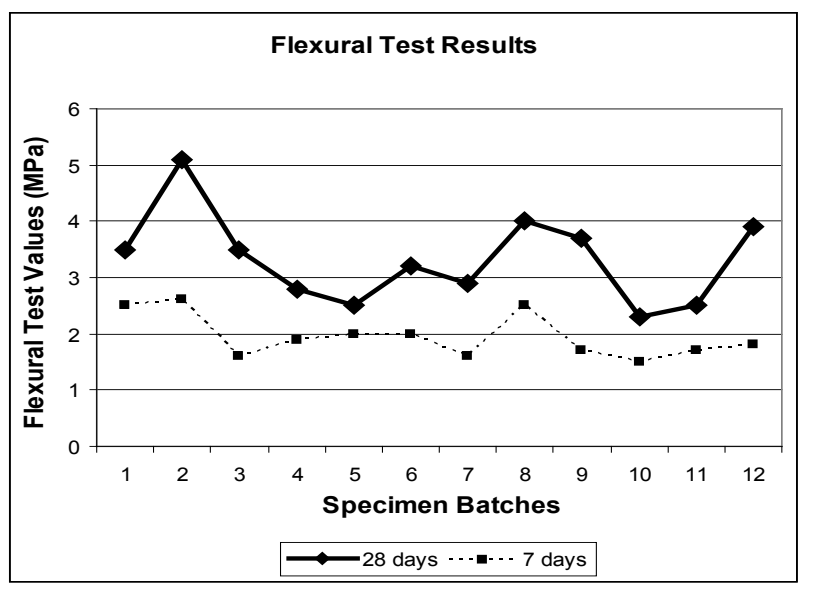

Figure 4. Flexural Result Charts

\section{Conclusions}

In addition to the environmental protection benefits by reducing the volume of the greenhouse gases emissions, the use of fly ash in the construction domain contributes also to the reduction of the cementitious cost because the fly ash is cheaper compared to the cement. For developing countries, the economic factor is very important especially for designing concrete structures where; in many cases; structure loading forces are not higher. The present study may inspire the actors in the construction domain by choosing appropriate percentage of the fly ash to use in cementitious materials according to the pre-established limits of structure loading.

\section{ACKNOWLEDGEMENTS}

The author would like to sincerely thank all those who contributed to the laboratory facilities for making and testing the fly ash samples.

\section{REFERENCES}

[1] Malhotra, V.M., and P.K. Mehta, High- Performance, HighVolume Fly Ash Concrete, Ottawa. 2002, 101 pp

[2] Confederation of Indian Industry, Centre of Excellence for Sustainable Development, For obtaining a superior performance of HVFAC, New Delhi, 2005

[3] Vargas, José A., A Designer's View of Fly Ash Concrete, USA, 2007

[4] Ehrenberg, A.Geisler, J.,Ecological Properties of Blast- furnace cement-part of life cycle, Germany, 1997

[5] Langley, W.S., and G.H.Leaman, Practical uses for HighVolume Fly Ash Concrete, Germany,1998 